\title{
PENERAPAN PROSES HIERARKI ANALITIK (PHA) DALAM MENGATASI MASALAH KEMACETAN LALU LINTAS DI KOTA AMBON
}

\author{
Mozart W. Talakua ${ }^{1 *}$, Jemsri S. Batlajery ${ }^{2}$ \\ ${ }^{1,2}$ Jurusan Matemtika, Fakultas MIPA, Universitas Pattimura \\ Jln. Ir. M. Putuhena, Kampus Unpatti, Poka-Ambon, 97233, Indonesia \\ e-mail: ${ }^{1 *}$ ocat_08@yahoo.com ; ${ }^{2}$ jemsribatlajery17@gmail.com \\ Corresponding Author *
}

\begin{abstract}
Abstrak
Kepadatan lalu lintas yang meningkat akhir-akhir ini di Kota Ambon telah menimbulkan masalah yang cukup serius, seperti waktu tempuh perjalanan yang bertambah lama dan pencemaran udara yang semakin meningkat. Masalah kemacetan di Kota Ambon ini dapat diselesaikan dengan menggunakan metode Proses Hierarki Analitik (PHA). Data penelitian ini diperoleh dengan menyebarkan 100 kuesioner kepada masyarakat Kota Ambon yang memiliki Surat Izin Mengemudi (SIM). Hasil penelitian ini dengan menggunakan metode Proses Hierarki Analitik ternyata masyarakat Kota Ambon yang memiliki SIM menganggap aspek pengelolaan yang paling mempengaruhi kemacetan yaitu sebesar $45,2 \%$; sedangkan yang menjadi prioritas utama dalam mengatasi kemacetan adalah pembenahan jalur angkutan umum sebesar 19,6\%.
\end{abstract}

Kata Kunci : Transportasi, Kebijakan, Sistem, Transportasi Umum.

\section{APPLICATION OF ANALYTIC HIERARCHY PROCESS TO REDUCE TRAFFIC DENSITY IN AMBON CITY}

\begin{abstract}
The recent increase in traffic density in Ambon City has caused quite serious problems, such as prolonged travel and increased air pollution. The problem of congestion in Ambon City can be solved by using Analytic Hierarchy Process (AHP) method. This research data was obtained by spreading 100 questionnaires to people in Ambon City who have Driver's License (DL). The result of this research by using AHP method was people in Ambon City who have DL consider management aspect which most influence jams that is equal to $45,2 \%$; while the main priority in overcoming the congestion is the improvement of the public transport route $19,6 \%$.
\end{abstract}

Keywords: Transportation, Policy, System, Public Transport. 


\section{PENDAHULUAN}

Dewasa ini kepadatan lalu lintas di dalam Kota Ambon semakin meningkat sehingga sering menimbulkan kemacetan terutama di jalur-jalur protokol di dalam pusat kota dan jalan-jalan utama lainnya. Peningkatan jumlah kendaraan bermotor pada umumnya disebabkan oleh beberapa faktor, diantaranya karena peningkatan jumlah permintaan kendaraan bermotor dan tidak nyamannya angkutan umum yang ada di dalam kota, serta jarak tempuh antara pusat kota dan pinggiran kota yang berjauhan. Faktor-faktor tersebut yang mendorong masyarakat untuk memiliki kendaraan pribadi. Selanjutnya, kemacetan lalu lintas juga dipengaruhi oleh rendahnya kinerja lembaga-lembaga yang bertanggung jawab terhadap masalah transportasi perkotaan serta rendahnya tingkat disiplin pemakai jalan yang menyebabkan kemacetan sering terjadi [2].

Karena itu, sangat diperlukan kebijakan-kebijakan yang dalam hal ini adalah alternatif-alternatif untuk membenahi masalah kemacetan di ruas-ruas jalan utama di Kota Ambon seperti: menambah lebar jalan, mengoptimalkan pemakaian kendaraan pribadi, mengoptimalkan jumlah kendaraan umum, membenahi area parkir, pembenahan jalur angkutan umum dan membuat jalan layang. Untuk mengetahui alternatif manakah yang perlu diprioritaskan dalam mengatasi masalah kemacetan di Kota Ambon, maka dipakai Metode Proses Hierarki Analitik (PHA) yang dikembangkan oleh Thomas L. Saaty pada tahun 1970-an untuk mengorganisasikan informasi dan judgment dalam memilih alternatif yang paling disukai. Model pendukung keputusan ini akan menguraikan masalah multi faktor yang kompleks menjadi suatu hirarki. Menurut Saaty, hirarki didefinisikan sebagai suatu representasi dari sebuah permasalahan yang kompleks dalam suatu struktur multi level dimana level pertama adalah tujuan, yang diikuti level faktor, kriteria, sub kriteria, dan seterusnya ke bawah hingga level terakhir yaitu alternatif [11].

\section{Tinjauan Pustaka}

\subsection{Proses Hierarki Analitik (PHA)}

Proses Hierarki Analitik (PHA) merupakan sistem pembuat keputusan dengan menggunakan model matematis. PHA membantu dalam menentukan prioritas dari beberapa kriteria dengan melakukan analisa perbandingan berpasangan dari masing-masing kriteria[3]. PHA juga merupakan suatu model yang luwes yang memberikan kesempatan bagi perorangan atau kelompok untuk membangun gagasan-gagasan dan mendefinisikan persoalan dengan cara membuat asumsi mereka masing-masing dan memperoleh pemecahan yang diinginkan darinya. Dalam menyelesaikan persoalan dengan PHA ada beberapa prinsip yang harus dipahami diantaranya yaitu [10] :

\section{1) Decompocition}

Setelah permasalahan didefinisikan, maka perlu dilakukan decompocition yaitu memecah permasalahan awal menjadi beberapa kriteria. Jika ingin mendapatkan hasil yang baik, pemecahan juga dilakukan terhadap kriteria-kriteria sampai tidak dapat dilakukan pemecahan lebih lanjut sehingga didapatkan beberapa tingkatan dari persoalan tadi. Karena alasan ini, maka proses analisis ini dinamakan hierarki. Ada dua jenis hierarki, yaitu hierarki lengkap dan tidak lengkap. Dalam hierarki lengkap, semua elemen pada suatu tingkatan memiliki relasi dengan semua elemen yang ada pada tingkatan berikutnya, namun jika tidak, maka dinamakan hierarki tidak lengkap.

\section{2) Comparative Judgement}

Tahap ini adalah membuat penilaian tentang kepentingan relatif dua elemen pada suatu tingkatan tertentu dalam kaitannya dengan tingkatan yang ada di atasnya. Penilaian ini merupakan inti dari PHA, karena penilaian akan berpengaruh terhadap prioritas elemen-elemennya. Hasil dari penilaian ini akan lebih mudah bila disajikan dalam bentuk matriks yang dinamakan matriks pairwise comparison.

Supaya memperoleh skala yang sesuai ketika membandingkan dua elemen, maka seseorang yang akan memberikan jawaban harus mengerti seluruh elemen-elemen yang akan dibandingkan dan relevansinya terhadap kriteria atau tujuan yang ingin dicapai. Dalam penilaian kepentingan relatif dua elemen berlaku aksioma reciprocal artinya jika suatu elemen $i$ dinilai 3 kali lebih penting dibanding $j$, maka elemen $j$ harus sama dengan 1/3 kali pentingnya dibanding elemen $i$. Selain itu, perbandingan 
dua elemen yang menghasilkan angka 1 berarti kedua elemen sama penting. Dua elemen yang berlainan juga dapat saja dinilai sama penting. Jika terdapat $n$ elemen, maka akan diperoleh matriks perbandingan berpasangan (pairwise comparison) berukuran $n \times n$.

\section{3) Synthesis of Priority}

Tahap ini dilakukan dengan menggunakan eigen vector method untuk mendapatkan bobot relatif bagi unsur-unsur pengambilan keputusan.

\section{4) Logical Consistency}

Logical consistency merupakan karakteristik penting PHA. Hal ini dicapai dengan mengagresikan seluruh vektor eigen yang diperoleh dari berbagai tingkatan hierarki dan selanjutnya diperoleh suatu vector composite tertimbang yang menghasilkan urutan pengambilan keputusan.

Hierarki adalah metode yang paling mudah untuk memahami masalah yang kompleks dimana masalah tersebut dipecah menjadi kriteria-kriteria, kemudian kriteria-kriteria tersebut disusun secara hierarki dan melakukan penilaian atas kriteria-kriteria tersebut sekaligus menentukan keputusan apa yang akan diambil. Secara umum, hierarki dapat dibagi dua jenis yaitu[8]:

a. Hierarki struktural, menguraikan masalah yang kompleks menjadi bagian-bagiannya atau elemen-elemennya menurut ciri atau besaran tententu seperti jumlah, bentuk, ukuran, atau warna.

b. Hierarki fungsional, menguraikan masalah yang kompleks menjadi bagian yang sesuai hubungan esensialnya.

Penyusunan hierarki dilakukan dengan menggambarkan sebuah struktur yang memuat permasalahan yang kemudian dipecah menjadi kriteria-kriteria yang saling relevan. Susunan hierarki adalah sebagai berikut[4]:

a. Tingkat 1: Fokus/sasaran utama

b. Tingkat 2: Faktor/kriteria

c. Tingkat 3: Sub-faktor

d. Tingkat 4: Obyektif

e. Tingkat 5: Alternatif

\subsection{Matriks}

\section{Definisi 2.1:}

Matriks adalah suatu susunan bilangan-bilangan berbentuk segiempat. Bilangan-bilangan dalam susunan itu disebut anggota dalam matriks [1].

Ukuran matriks diberikan oleh jumlah baris dan jumlah kolom. Suatu matriks dengan hanya satu kolom disebut matriks kolom dan suatu matriks dengan hanya satu baris disebut matriks baris. Anggota pada baris $i$ dan kolom $j$ dari sebuah matriks A dapat dinyatakan $a_{i j}$. Matriks dinotasikan dengan huruf kapital $A B$ dan sebagainya. Bentuk matriks secara umum bentuk matriks yaitu :

$$
A_{m \times n}=\left[\begin{array}{cccc}
a_{11} & a_{12} & \cdots & a_{1 n} \\
a_{21} & a_{22} & \ldots & a_{2 n} \\
\vdots & \vdots & \ddots & \vdots \\
a_{m 1} & a_{m 2} & \cdots & a_{m n}
\end{array}\right]
$$

Anggota suatu matriks berindeks rangkap, misalnya pada $A$ di atas $a_{21}$ menyatakan matriks $A$ berada pada baris ke-2 dan kolom ke-1, sedangkan matriks $A$ berordo $m \times n$ dan ditulis $A_{m \times n}$ [1].

\section{Defenisi 2.2:}

Jika $A$ adalah sebuah matriks berukuran $m \times r$ dan $B$ adalah sebuah matriks berukuran $r \times n$, maka hasil kali $A B$ adalah sebuah matriks berukuran $m \times n$ yang anggota-anggotanya didefinisikan yaitu untuk mencari anggota dalam baris $i$ pada kolom $j$ dari $A B$, pilih baris $i$ dari matriks $A$ dan kolom $j$ dari matriks $B$. Kalikan anggota-anggota yang bersesuaian dari baris dan kolom secara bersama-sama dan kemudian jumlahkan hasilnya. 


\subsection{Matriks Perbandingan Berpasangan}

Jika dipunyai pasangan berurutan $\left(w_{i}, w_{j}\right)$ dengan $i, j=1,2, \ldots, n$ maka pembandingan seluruh elemen dapat dinyatakan dengan

$$
w_{i} / w_{j}=a_{i j}
$$

Dalam hal ini $A=\left[a_{i j}\right]$ adalah matriks perbandingan yang unsur-unsurnya adalah $a_{i j}$, dengan $a_{i j}=1$ dan $a_{i j}=\frac{1}{a_{i j}}$.

Dari bentuk di atas, bila masing-masing bobot $w_{i}$ menjadi elemen vektor $W=\left[w_{1} w_{2} w_{3} \ldots w_{n}\right]^{T}$, maka dapat dituliskan:

$$
A W=\left[\begin{array}{cccc}
\frac{w_{1}}{w_{1}} & \frac{w_{1}}{w_{2}} & \cdots & \frac{w_{1}}{w_{n}} \\
\frac{w_{2}}{w_{1}} & \frac{w_{2}}{w_{2}} & \cdots & \frac{w_{2}}{w_{n}} \\
\vdots & \vdots & \ddots & \vdots \\
\frac{w_{n}}{w_{1}} & \frac{w_{n}}{w_{2}} & \cdots & \frac{w_{n}}{w_{n}}
\end{array}\right]\left[\begin{array}{c}
w_{1} \\
w_{2} \\
\vdots \\
w_{n}
\end{array}\right]=\left[\begin{array}{c}
n w_{1} \\
n w_{2} \\
\vdots \\
n w_{n}
\end{array}\right]=n W
$$

Dalam bentuk lain, dapat dituliskan:

$$
B W=\left[\begin{array}{cccc}
1 & b_{1,2} & \ldots & b_{1, n} \\
b_{1,2}^{-1} & 1 & \cdots & b_{2, n} \\
\vdots & \vdots & \ddots & \vdots \\
b_{1, n}^{-1} & b_{2, n}^{-1} & \cdots & 1
\end{array}\right]\left[\begin{array}{c}
w_{1} \\
w_{2} \\
\vdots \\
w_{n}
\end{array}\right]=\lambda_{\max }\left[\begin{array}{c}
w_{1} \\
w_{2} \\
\vdots \\
w_{n}
\end{array}\right]
$$

dimana $b_{i, j}=b_{j, i}^{-1}$ sehingga matriks $B$ semua elemennya positif dan saling berkebalikan secara diagonal (reciprocal matrix).

Untuk menuliskan matriks $B$ positif dan merupakan reciprocal matrix, maka komponen vektor eigen utamanya semua positif dan dapat dinormalisasi, diantaranya dengan bentuk[6]:

$$
\overline{w_{l}}=\frac{w_{i}}{\sum_{j=1}^{n} w_{j}} \rightarrow \sum_{j=1}^{n} \overline{w_{J}}=1
$$

Pada matriks $A$, terdapat sifat transitive consistency $\left(a_{i, j} \cdot a_{j, k}=a_{i, k}\right)$ dan reciprocalconsistency $\left(a_{i, j}=a_{j, i}^{-1}\right)$ sedang pada matriks $B$ belum tentu berlaku transitiveconsistency. Hubungan persamaan (1) dan (2) adalah $\lambda_{\max } \geq n$, sehingga bila, $B \rightarrow A$, yaitu $B$ lebih konsisten transitif maka $\lambda_{\max } \rightarrow n$.

\subsection{Penilaian Perbandingan Multi Partisipan}

Penilaian yang dilakukan oleh banyak partisipan akan menghasilkan pendapat yang berbeda satu sama lainnya. PHA hanya membutuhkan satu jawaban untuk matriks perbandingan. Jadi semua jawaban partisipan harus dirata- ratakan. Untuk itu metode perataan dengan rata-rata geometrik atau Geometric Mean.

Teori rata-rata geometrik menyatakan bahwa jika terdapat $n$ partisipan melakukan perbandingan berpasangan, maka terdapat $n$ jawaban nilai numerik untuk setiap pasangan. Untuk mendapatkan satu nilai tertentu dari semua nilai tersebut, masing-masing nilai harus dikalikan satu sama lain. Kemudian hasil perkalian dipangkatkan dengan $\frac{1}{n}$, secara matematis dapat dituliskan sebagai berikut[9]:

$$
a_{i j}=\sqrt[n]{\prod_{i=1}^{n} x_{i}}
$$

\subsection{Normalisasi}

Berdasarkan matriks perbandingan berpasangan tersebut akan dilakukan normalisasi dengan langkah-langkah sebagai berikut: 
a. Menjumlahkan nilai setiap baris ke $-i$ pada kolom ke $-j$ dalam matriks perbandingan berpasangan:

$$
S_{i j}=\sum_{i=1}^{n} a_{i j}, \text { untuk } i, j=1,2, \ldots, n
$$

b. Membagi nilai $a_{i j}$ pada setiap kolom dengan nilai $\left(S_{i j}\right)$ :

$$
V_{i j}=\frac{a_{i j}}{s_{i j}}, \text { untuk } i, j=1,2, \ldots, n
$$

c. Hitunglah prioritas relatif dari setiap kriteria dengan merata-ratakan bobot yang sudah dinormalisasi dari setiap baris ke $-i$. Prioritas relatif kriteria $i$ dilambangkan dengan $P_{i}$

$$
P_{i}=\frac{\sum_{i=1}^{n} V_{i j}}{n} \operatorname{untuk} i, j=1,2, \ldots, n
$$

\subsection{Uji Konsistensi Indeks dan Rasio}

Salah satu keutamaan model PHA yang membedakannya dengan model-model pengambilan keputusan yang lainnya adalah tidak adanya syarat konsistensi mutlak[5]. Dengan model PHA yang memakai persepsi decision maker sebagai inputnya maka ketidakkonsistenan mungkin terjadi karena manusia memiliki keterbatasan dalam menyatakan persepsinya secara konsisten terutama kalau harus membandingkan banyak kriteria.

Pengukuran konsistensi dari suatu matriks itu didasarkan atas nilai Eigen maksimum. Indeks konsistensi dari matriks berordo $n$ dapat diperoleh dengan rumus sebagai berikut:

$$
C I=\frac{\lambda_{\max }-n}{(n-1)}
$$

dimana :

$$
\begin{aligned}
& C I=\text { Rasio Penyimpangan (deviasi) konsistensi (consistency index) } \\
& \lambda_{\max }=\text { Nilai Eigen terbesar dari matriks berordo } n
\end{aligned}
$$

Nilai eigen Maksimum diperoleh dengan menjumlahkan hasil perkalian matriks perbandingan dengan vektor eigenutama (vektor prioritas) dan membaginya dengan banyak elemen, maka :

$$
\lambda_{\max }=\frac{\lambda}{n}
$$

Apabila $C I$ bernilai nol, maka matriks perbandingan berpasangan tersebut konsisten. Batas ketidakkonsistenan yang telah ditetapkan oleh Saaty ditentukan dengan menggunakan Consistency Ratio $(C R)$, yaitu didapatkan dari suatu eksperimen oleh Oak National Laboratory kemudian dikembangkan oleh Wharton School. Nilai ini bergantung pada ordo matriks $n$. Dengan demikian, Rasio Konsistensi dapat dirumuskan sebagai berikut :

$$
C R=\frac{C I}{R I}
$$

dimana :

$$
\begin{aligned}
& C R=\text { Consistency Ratio } \\
& R I=\text { Random Indeks }
\end{aligned}
$$

Tabel 1. Nilai Random Indeks (RI)

\begin{tabular}{|ccccccccccccccc|}
\hline$n$ & 1,2 & 3 & 4 & 5 & 6 & 7 & 8 & 9 & 10 & 11 & 12 & 13 & 14 & 15 \\
\hline$R I$ & 0,00 & 0,58 & 0,90 & 1,12 & 1,24 & 1,32 & 1,41 & 1,45 & 1,49 & 1,51 & 1,48 & 1,56 & 1,57 & 1,59 \\
\hline
\end{tabular}

Apabila matriks perbandingan berpasangan dengan nilai $C R \leq 0,1$, maka hasil penilaian tersebut dikatakan konsisten. Jika tidak maka penilaian perlu diulang untuk menemukan penyebab ketidakkonsistenan dan memperbaikinya [7]. 


\section{HASIL DAN PEMBAHASAN}

\subsection{Matriks Normalisasi}

Dilakukan normalisasi dengan mencari nilai $S_{i j}$ dengan menjumlahkan nilai setiap baris ke- $i$ pada kolom ke $-j$ dalam matriks perbandingan berpasangan atau menghitung jumlah setiap kolom pada matriks perbandingan berpasangan serta menghitung matriks prioritas relatif $(R)$ :

Matriks perbandingan berpasangan :

$$
\begin{aligned}
& {\left[\begin{array}{ccc}
1 & 2,047 & 0,707 \\
0,488 & 1 & 0,474 \\
1,414 & 2,109 & 1
\end{array}\right]} \\
& S_{i j}=2,9025,1562,181, \text { untuk } i, j=1,2, \ldots, n \\
& {\left[\begin{array}{lll}
0,345 & 0,397 & 0,324 \\
0,168 & 0,194 & 0,217 \\
0,487 & 0,409 & 0,459
\end{array}\right]} \\
& R=\left[\begin{array}{l}
0,355 \\
0,193 \\
0,452
\end{array}\right]
\end{aligned}
$$

\subsection{Perhitungan Nilai $\lambda_{\text {maks }}$}

\section{Menentukan Weighted Sum Vector}

Weighted Sum Vector ditentukan dengan cara mengalikan matriks perbandingan berpasangan dengan matriks prioritas relatif, hasilnya:

$$
\left[\begin{array}{ccc}
1 & 2,047 & 0,707 \\
0,488 & 1 & 0,474 \\
1,414 & 2,109 & 1
\end{array}\right]\left[\begin{array}{l}
0,355 \\
0,193 \\
0,452
\end{array}\right]=\left[\begin{array}{l}
1,070 \\
0,580 \\
1,361
\end{array}\right]
$$

\section{Menentukan Consistency Vektor}

Consistency Vektor ditentukan dengan cara membagi nilai Weighted Sum Vector dengan nilai-nilai pada matriks Prioritas Relatif hasilnya:

$$
\left[\begin{array}{l}
1,070 / 0,355 \\
0,580 / 0,193 \\
1,361 / 0,452
\end{array}\right]=\left[\begin{array}{l}
3,014 \\
3,005 \\
3,011
\end{array}\right]
$$

Menentukan Nilai $\lambda_{\text {maks }}$

$$
\begin{aligned}
\lambda_{\text {maks }} & =\frac{(3,014+3,005+3,011)}{n}=\frac{9,030}{3}=3,010 \\
C I & =\frac{\lambda_{\text {maks }}-n}{n-1} \\
& =0,005 \\
C R & =\frac{C I}{R I}=\frac{0,005}{0,52}=0,01
\end{aligned}
$$

Jadi

$$
\begin{array}{ll}
\lambda_{\text {maks }} & =3,010(\text { mendekati } n) \\
C I & =0,005(\text { cukup kecil }) \\
C R & =0,01 \leq 0,1(\text { hasil penilaian konsisten) }
\end{array}
$$

\subsection{Perhitungan Faktor Pembobotan Hierarki Untuk Aspek Lingkungan}

\section{Matriks Perbandingan Berpasangan}

Berdasarkan hasil perhitungan maka diperoleh matriks perbandingan aspek lingkungan terhadap ke enam cara penanganan lalu lintas dapat dilihat pada Tabel 2 berikut : 
Tabel 2. Matriks Perbandingan Aspek Lingkungan Terhadap

\begin{tabular}{|ccccccc|}
\multicolumn{7}{c}{ Keenam Cara Penanganan Lalu Lintas } \\
\hline & E & F & G & H & I & J \\
\hline E & 1 & 1,373 & 1,089 & 0,711 & 0,818 & 0,725 \\
\hline F & 0,728 & 1 & 0,834 & 0,698 & 0,559 & 0,644 \\
\hline G & 0,918 & 1,2 & 1 & 0,951 & 0,704 & 0,847 \\
\hline H & 1,406 & 1,432 & 1,052 & 1 & 0,87 & 1,041 \\
\hline I & 1,222 & 1,789 & 1,421 & 1,149 & 1 & 1,179 \\
\hline J & 1,379 & 1,553 & 1,181 & 0,961 & 0,848 & 1 \\
\hline
\end{tabular}

\section{Matriks Normalisasi}

Berdasarkan matriks perbandingan berpasangan tersebut dilakukan normalisasi sebagai berikut : Matriks Perbandingan Berpasangan untuk Aspek Lingkungan

$$
\begin{aligned}
& {\left[\begin{array}{cccccc}
1 & 1,373 & 1,089 & 0,711 & 0,818 & 0,725 \\
0,728 & 1 & 0,834 & 0,698 & 0,559 & 0,644 \\
0,918 & 1,2 & 1 & 0,951 & 0,704 & 0,847 \\
1,406 & 1,432 & 1,052 & 1 & 0,870 & 1,041 \\
1,222 & 1,789 & 1,421 & 1,149 & 1 & 1,179 \\
1,379 & 1,553 & 1,181 & 0,961 & 0,848 & 1
\end{array}\right]} \\
& S_{i j}=6,6538,3476,5775,474,7995,436 \text { untuk } i, j=1,2, \ldots, n \\
& {\left[\begin{array}{llllll}
0,150 & 0,164 & 0,166 & 0,130 & 0,170 & 0,133 \\
0,109 & 0,120 & 0,127 & 0,128 & 0,116 & 0,118 \\
0,138 & 0,144 & 0,152 & 0,174 & 0,147 & 0,156 \\
0,211 & 0,172 & 0,160 & 0,183 & 0,181 & 0,191 \\
0,184 & 0,214 & 0,216 & 0,210 & 0,208 & 0,217 \\
0,207 & 0,186 & 0,180 & 0,176 & 0,177 & 0,184
\end{array}\right]}
\end{aligned}
$$

Hitung prioritas relatif dengan merata-ratakan nilai untuk setiap baris dan mengubah menjadi matriks prioritas relatif $(R)$.

$$
R=\left[\begin{array}{l}
0,152 \\
0,120 \\
0,152 \\
0,183 \\
0,208 \\
0,185
\end{array}\right]
$$

\section{Perhitungan Nilai $\lambda_{\text {maks }}$}

Menentukan Weighted Sum Vector

$$
\left[\begin{array}{cccccc}
1 & 1,373 & 1,089 & 0,711 & 0,818 & 0,725 \\
0,728 & 1 & 0,834 & 0,698 & 0,559 & 0,644 \\
0,918 & 1,2 & 1 & 0,951 & 0,704 & 0,847 \\
1,406 & 1,432 & 1,052 & 1 & 0,870 & 1,041 \\
1,222 & 1,789 & 1,421 & 1,149 & 1 & 1,179 \\
1,379 & 1,553 & 1,181 & 0,961 & 0,848 & 1
\end{array}\right]\left[\begin{array}{l}
0,152 \\
0,120 \\
0,152 \\
0,183 \\
0,208 \\
0,185
\end{array}\right]=\left[\begin{array}{l}
0,917 \\
0,721 \\
0,913 \\
1,102 \\
1,253 \\
1,113
\end{array}\right]
$$

Menentukan Consistency Vektor

$$
\left[\begin{array}{l}
0,917 / 0,152 \\
0,721 / 0,120 \\
0,913 / 0,152 \\
1,102 / 0,183 \\
1,253 / 0,208 \\
1,113 / 0,185
\end{array}\right]=\left[\begin{array}{l}
6,033 \\
6,008 \\
6,007 \\
6,022 \\
6,024 \\
6,016
\end{array}\right]
$$

Menghitung Nilai $\lambda_{\text {maks }}$ 


$$
\begin{aligned}
\lambda_{\text {maks }} & =\frac{36,11}{6}=6,018 \\
C I & =\frac{\lambda_{\text {maks }}-n}{n-1} \\
& =\frac{6,018-6}{6-1}=0,004 \\
C R & =\frac{C I}{R I}=\frac{0,002}{1,25}=0,003
\end{aligned}
$$

Jadi $\lambda_{\text {maks }}=6,018$ (mendekati $n$ ), $C I=0,004$ (cukup kecil); $C R=0,003 \leq 0,1$ (hasil penilaian konsisten.

\subsection{Perhitungan Faktor Pembobotan Hierarki Untuk Aspek Ekonomi}

\section{Matriks Perbandingan Berpasangan}

Berdasarkan hasil perhitungan maka diperoleh matriks perbandingan aspek ekonomi terhadap keenam cara penanganan lalu lintas dapat dilihat pada Tabel 3 berikut :

Tabel 3. Matriks Perbandingan Aspek Ekonomi Terhadap

\begin{tabular}{|ccccccc|}
\multicolumn{7}{c|}{ Keenam Cara Penanganan Lalu Lintas } \\
\hline & E & F & G & H & I & J \\
\hline E & 1 & 1,233 & 1,118 & 0,972 & 0,809 & 0,872 \\
\hline F & 0,811 & 1 & 1,086 & 0,810 & 0,786 & 0,846 \\
\hline G & 0,894 & 0,921 & 1 & 1,107 & 0,937 & 0,939 \\
\hline H & 1,029 & 1,235 & 0,903 & 1 & 1,183 & 1,176 \\
\hline I & 1,236 & 1,272 & 1,067 & 0,845 & 1 & 1,191 \\
\hline J & 1,146 & 1,182 & 1,066 & 0,850 & 0,840 & 1 \\
\hline
\end{tabular}

\section{Matriks Normalisasi}

Berdasarkan matriks perbandingan berpasangan tersebut dilakukan normalisasi sebagai berikut: Cari nilai $S_{i j}$ dengan menjumlahkan nilai setiap baris ke- $i$ pada kolom ke-j dalam matriks perbandingan berpasangan atau menghitung jumlah setiap kolom pada matriks perbandingan berpasangan:

Matriks Perbandingan Berpasangan $(R)$ untuk Aspek Ekonomi .

$$
\begin{aligned}
& {\left[\begin{array}{cccccc}
1 & 1,233 & 1,118 & 0,972 & 0,809 & 0,872 \\
0,811 & 1 & 1,086 & 0,810 & 0,786 & 0,846 \\
0,894 & 0,921 & 1 & 1,107 & 0,937 & 0,939 \\
1,029 & 1,235 & 0,903 & 1 & 1,183 & 1,176 \\
1,236 & 1,272 & 1,067 & 0,845 & 1 & 1,191 \\
1,146 & 1,182 & 1,066 & 0,850 & 0,840 & 1
\end{array}\right]} \\
& S_{i j}=6,116 \quad 6,8436,2405,5845,555 \quad 6,024 \text { untuk } i, j=1,2, \ldots, n
\end{aligned}
$$

Membagi nilai $a_{i j}$ pada setiap kolom dengan nilai $S_{i j}$ :

$\left[\begin{array}{llllll}0,164 & 0,180 & 0,179 & 0,174 & 0,146 & 0,145 \\ 0,133 & 0,146 & 0,174 & 0,145 & 0,141 & 0,140 \\ 0,146 & 0,135 & 0,160 & 0,198 & 0,169 & 0,156 \\ 0,168 & 0,180 & 0,145 & 0,179 & 0,213 & 0,195 \\ 0,202 & 0,186 & 0,171 & 0,151 & 0,180 & 0,198 \\ 0,187 & 0,173 & 0,171 & 0,152 & 0,151 & 0,166\end{array}\right]$




$$
R=\left[\begin{array}{l}
0,165 \\
0,147 \\
0,161 \\
0,180 \\
0,181 \\
0,167
\end{array}\right]
$$

\section{Perhitungan Nilai $\lambda_{\text {maks }}$}

Menentukan Weighted Sum Vector

$$
\left[\begin{array}{cccccc}
1 & 1,233 & 1,118 & 0,972 & 0,809 & 0,872 \\
0,811 & 1 & 1,086 & 0,810 & 0,786 & 0,846 \\
0,894 & 0,921 & 1 & 1,107 & 0,937 & 0,939 \\
1,029 & 1,235 & 0,903 & 1 & 1,183 & 1,176 \\
1,236 & 1,272 & 1,067 & 0,845 & 1 & 1,191 \\
1,146 & 1,182 & 1,066 & 0,850 & 0,840 & 1
\end{array}\right]\left[\begin{array}{c}
0,165 \\
0,147 \\
0,161 \\
0,180 \\
0,181 \\
0,167
\end{array}\right]=\left[\begin{array}{c}
0,993 \\
0,885 \\
0,970 \\
1,087 \\
1,095 \\
1,007
\end{array}\right]
$$

Menentukan Consistency Vektor

$$
\left[\begin{array}{c}
0,993 / 0,165 \\
0,885 / 0,147 \\
0,97 / 0,161 \\
1,087 / 0,180 \\
1,095 / 0,181 \\
1,007 / 0,167
\end{array}\right]=\left[\begin{array}{l}
6,018 \\
6,020 \\
6,025 \\
6,039 \\
6,050 \\
6,030
\end{array}\right]
$$

Menghitung Nilai $\lambda_{\text {maks }}$

$$
\begin{aligned}
\lambda_{\text {maks }} & =\frac{6,018+6,020+6,025+6,039+6,050+6,030}{n}=\frac{36,182}{6}=6,03 \\
C I & =\frac{\lambda_{\text {maks }}-n}{n-1} \\
& =\frac{6,03-6}{6-1}=0,006 \\
C R & =\frac{C I}{R I}=\frac{0,006}{1,25}=0,005
\end{aligned}
$$

Jadi: $\lambda_{\text {maks }}=6,03$ (mendekati $n$ ), $C I=0,006$ (cukup kecil); $C R=0,005 \leq 0,1$ (hasil penilaian konsisten).

\subsection{Perhitungan Faktor Pembobotan Hierarki Untuk Aspek Pengelolaan}

\section{Matriks Perbandingan Berpasangan}

Berdasarkan hasil perhitungan maka diperoleh matriks perbandingan aspek pengelolaan terhadap keenam penanganan lalu lintas dapat dilihat pada Tabel 4 berikut :

Tabel 4. Matriks Perbandingan Aspek Pengelolaan Terhadap Ke Enam Cara Penanganan Lalu Lintas

\begin{tabular}{|ccccccc|}
\hline & E & F & G & H & I & J \\
\hline E & 1 & 1,687 & 1,222 & 1,010 & 0,890 & 1,150 \\
\hline F & 0,593 & 1 & 0,898 & 0,882 & 0,664 & 0,748 \\
\hline G & 0,818 & 1,113 & 1 & 1,136 & 0,855 & 1,113 \\
\hline H & 0,990 & 1,133 & 0,880 & 1 & 0,839 & 1,123 \\
\hline I & 1,124 & 1,506 & 1,170 & 1,192 & 1 & 1,071 \\
\hline J & 0,870 & 1,337 & 0,898 & 0,891 & 0,934 & 1 \\
\hline
\end{tabular}

\section{Matriks Normalisasi}

Berdasarkan matriks perbandingan berpasangan tersebut dilakukan normalisasi sebagai berikut: 


$$
\begin{aligned}
& {\left[\begin{array}{cccccc}
1 & 1,687 & 1,222 & 1,010 & 0,890 & 1,150 \\
0,593 & 1 & 0,898 & 0,882 & 0,664 & 0,748 \\
0,818 & 1,113 & 1 & 1,136 & 0,855 & 1,113 \\
0,990 & 1,133 & 0,880 & 1 & 0,839 & 1,123 \\
1,124 & 1,506 & 1,170 & 1,192 & 1 & 1,071 \\
0,870 & 1,337 & 0,898 & 0,891 & 0,934 & 1
\end{array}\right]} \\
& S_{i j}=5,3957,7766,0686,1115,1826,205 \text { untuk } i, j=1,2, \ldots, n
\end{aligned}
$$

Membagi nilai $a_{i j}$ pada setiap kolom dengan nilai $S_{i j}$ :

$\left[\begin{array}{llllll}0,185 & 0,217 & 0,201 & 0,165 & 0,172 & 0,185 \\ 0,110 & 0,129 & 0,148 & 0,144 & 0,128 & 0,121 \\ 0,152 & 0,143 & 0,165 & 0,186 & 0,165 & 0,179 \\ 0,184 & 0,146 & 0,145 & 0,164 & 0,162 & 0,181 \\ 0,208 & 0,194 & 0,193 & 0,195 & 0,193 & 0,173 \\ 0,161 & 0,172 & 0,148 & 0,146 & 0,180 & 0,161\end{array}\right]$

Hitung prioritas relatif dengan merata-ratakan nilai untuk setiap baris dan mengubah menjadi matriks

Matriks Prioritas Relatif $=\left[\begin{array}{c}0,188 \\ 0,130 \\ 0,165 \\ 0,163 \\ 0,193 \\ 0,161\end{array}\right]$

\subsubsection{Perhitungan Nilai $\lambda_{\text {maks }}$}

Menentukan Weighted Sum Vector

$\left[\begin{array}{cccccc}1 & 1,687 & 1,222 & 1,010 & 0,890 & 1,150 \\ 0,593 & 1 & 0,898 & 0,882 & 0,664 & 0,748 \\ 0,818 & 1,113 & 1 & 1,136 & 0,855 & 1,113 \\ 0,990 & 1,133 & 0,880 & 1 & 0,839 & 1,123 \\ 1,124 & 1,506 & 1,170 & 1,192 & 1 & 1,071 \\ 0,870 & 1,337 & 0,898 & 0,891 & 0,934 & 1\end{array}\right]\left[\begin{array}{c}0,188 \\ 0,130 \\ 0,165 \\ 0,163 \\ 0,193 \\ 0,161\end{array}\right]=\left[\begin{array}{c}1,130 \\ 0,782 \\ 0,993 \\ 0,984 \\ 1,160 \\ 0,972\end{array}\right]$

Menentukan Consistency Vektor

Menghitung Nilai $\lambda_{\text {maks }}$

$$
\left[\begin{array}{l}
1,130 / 0,188 \\
0,782 / 0,130 \\
0,993 / 0,165 \\
0,984 / 0,163 \\
1,160 / 0,193 \\
0,972 / 0,161
\end{array}\right]=\left[\begin{array}{l}
6,011 \\
6,015 \\
6,018 \\
6,037 \\
6,010 \\
6,037
\end{array}\right]
$$

$$
\begin{aligned}
\lambda_{\text {maks }} & =\frac{(6,011+6,015+6,018+6,037+6,010+6,037)}{n}=\frac{36,128}{6}=6,021 \\
C I & =\frac{\lambda_{\text {maks }}-n}{n-1} \\
& =\frac{6,01-6}{6-1}=0,004 \\
C R=\frac{C I}{R I} & =\frac{0,004}{1,25}=0,003
\end{aligned}
$$

Jadi : $\lambda_{\text {maks }}=6,021$ (mendekati $n$ ), $C I=0,004$ (cukup kecil); $C R=0,003 \leq 0,1$ (hasil penilaian konsisten) 


\subsection{Perhitungan Total Rangking/Prioritas Global}

\section{Faktor Evaluasi Total}

Dari seluruh evaluasi yang dilakukann terhadap ke-4 aspek yakni Aspek Lingkungan, Aspek Ekonomi, Aspek Pengelolaan yang selanjutnya dikaitkan dengan prioritas relatif untuk masing-masing aspek. Dengan demikian kita peroleh tabel hubungan antara tabel dengan alternatif:

Tabel 5. Matriks Faktor Pembobotan Hirarki Untuk Perbandingan Semua Aspek Dengan Enam Cara Penanganan Lalu Lintas

\begin{tabular}{|c|c|c|c|}
\hline & $\begin{array}{c}\text { Aspek } \\
\text { Lingkungan }\end{array}$ & $\begin{array}{c}\text { Aspek } \\
\text { Ekonomi }\end{array}$ & $\begin{array}{c}\text { Aspek } \\
\text { Pengelolaan }\end{array}$ \\
\hline E & 0,152 & 0,165 & 0,188 \\
\hline F & 0,120 & 0,147 & 0,130 \\
\hline G & 0,152 & 0,161 & 0,165 \\
\hline H & 0,183 & 0,180 & 0,163 \\
\hline I & 0,208 & 0,181 & 0,193 \\
\hline J & 0,185 & 0,167 & 0,161 \\
\hline
\end{tabular}

\section{Total Rangking}

Untuk mencari total rangking adalah dengan cara mengalikan faktor evaluasi masing-masing aspek dengan faktor bobot :

$$
\left[\begin{array}{lll}
0,152 & 0,165 & 0,188 \\
0,120 & 0,147 & 0,130 \\
0,152 & 0,161 & 0,165 \\
0,183 & 0,180 & 0,163 \\
0,208 & 0,181 & 0,193 \\
0,185 & 0,167 & 0,161
\end{array}\right]\left[\begin{array}{l}
0,355 \\
0,193 \\
0,452
\end{array}\right]=\left[\begin{array}{l}
0,171 \\
0,130 \\
0,160 \\
0,173 \\
0,196 \\
0,170
\end{array}\right]
$$

Hasil Perhitungan : $\quad \mathrm{E}=0,171$

$$
\begin{aligned}
& F=0,130 \\
& G=0,160 \\
& H=0,173 \\
& I=0,196 \\
& J=0,170
\end{aligned}
$$

Dari hasil perhitungan di atas, aspek yang paling berpengaruh terhadap kemacetan lalu lintas di Kota Ambon adalah aspek pengelolaan, yaitu 0,452, diikuti aspek lingkungan 0,355 dan aspek ekonomi 0,193 . Sedangkan yang menjadi proritas utama dalam mengatasi kemacetan adalah pembenahan jalur angkutan umum (I) sebesar 0,196; diikuti, membuat jalan layang (H) sebesar 0,173; menambah lebar jalan (E) sebesar 0,171; membenahi area parkir (J) sebesar 0,170 dan mengoptimalkan jumlah transportasi umum $(G)$ sebesar 0,160. Sedangkan yang menjadi prioritas terakhir adalah mengoptimalkan pemakaian kendaraan pribadi (F) sebesar 0,130.

\section{KESIMPULAN}

Adapun kesimpulan yang dapat diambil dari penelitian ini adalah bahwa berdasarkan hasil perhitungan dengan menggunakan PHA ternatif yang harus diprioritaskan untuk menurunkan kepadatan lalu lintas kendaraan bermotor adalah pembenahan jalur angkutan umum sebesar 19,6\%; pembuatan jalan layang sebesar 17,3\%; menambah lebar jalan sebesar 17,1\%; membenahi area parkir sebesar $17 \%$ dan mengoptimalkan jumlah angkutan umum sebesar $16 \%$. Sedangkan yang menjadi prioritas terakhir adalah mengoptimalkan pemakaian kendaraan pribadi sebesar $13 \%$. 


\section{Daftar Pustaka}

[1] Anton, Howard dan Rorres, Chris, Elementary Linear Algebra,10th Edition, New York : John Wiley \& Sons, Inc, 2000.

[2] Arifin, Sinta, Skripsi Pengambilan Keputusan untuk Penilaian Kinerja Menggunakan Analytic Hierarchy Process (AHP), Yogyakarta: Universitas Negeri Yogyakata., 2013.

[3] Brunelli, M, Introduction to the Analytic Hierarchy Proces, New York: Springer., 2015.

[4] Hastuti, D. Dwi Puji, Proses Hierarki Analisis (PHA) dalam Pengambilan Keputusan Multikriteria, Jurusan Pendidikan Matematika: Universitas Negeri Yogyakata, 2010.

[5] Kelelufna, Salomo, Skripsi Aplikasi Proses Hirarki Analitik (PHA) Sistem Pemilihan Keputusan Pembelian Sepeda Motor, Jurusan Matematika: Universitas Pattimura., 2016.

[6] Manggiora, G. M, Computer-Aided Decision Making in Pharmaceutical Research, Proceeding of the Beilstein-Institut Workshop, Bozen, Italy.," 2002.

[7] E. Mu, Practical Decision Making, Springer Briefs in Operations Research.," 2017.

[8] Permadi, Bambang, AHP Pusat Antar Universitas - Studi Ekonomi, Jakarta: Universitas Indonesia., 1992.

[9] Saaty, Thomas L, Pengambilan Keputusan Bagi Para Pemimpin terjemahan Liana Setiono, Jakarta: Pustaka Binaman Pressindo, 1993.

[10] Sukarto, Haryono, Pemilihan Model Transportasi di DKI Jakarta dengan AnalisisKebijakan "Proses Hierarki Analitik”, Jurnal Teknik Sipil , p. Vol. 3 No.1, 2006.

[11] Marimin, Teknik dan Aplikasi Pengambilan Keputusan Kriteria Majemuk., Jakarta : PT. Grasindo., 2004. 